\title{
関東地区相互貸借実務担当者懇談会記録
}

\section{Proceedings of the Meeting on Interlibrary-Loan Service}

日 時，昭和 51 年 9 月 28 日（火）

pm $1: 30 \sim 4: 30$

場 所 東邦大学 1 号館 図書館研究棟 $8 \mathrm{~F}$

出席 27 館 36 名

司 会 I L L 懇話会（東女：西岡）

はじめに

医学図書館における相互貸借業務は今やレファレンス 活動の一環として必要欠くべからざるものになってきて いる。又他種図書館諸グループと比較しても医学図書館 界の文献相互貸借のネットワークは, その歷史, 実績を みても誇るべき協力体制であると思う。しかしそれにも かかわらず依然として「日本医学図書館協会相互利用規 約」から，このネットワークの利用については “好意と 特典”であるといら字句は消えない。我々実務担当者と しては図書館サービスとして完全に定着し，専任の担当 となっている現実（すべての図書館でそうではないかも 知れないが）をみると好意と特典という関係は実感にそ ぐわないような気もするが削除できない理由があるのだ ろう。そのあたりがこの協力体制の限界を示唆している のかも知れない。そういう状況ではあっても, 文献相互 貸借業務の重要性はいささかも減じられるものではない。 迅速且つ正確に文献の相互利用が行なわれるよう常に努 力しなければならないと思う。

さて, 同様の懇談会が開催されたのは今回で 2 度目で ある。第 1 回は昭和 50 年 9 月 5 日, 場所は同じ東邦大 学で関東地区相互貸借担当者 37 名の出席を得て行なわ れた。この時の議題は，既に協会全加盟館に配布済の 「相互貸借マニュアル」の草案を土台に各館が意見を持 ちより，検討するというものであった。慇談会は関東地 区医学図書館協議会の活動としてテレックス孤話会（現 ILL 愁話会）が企画，運営したものである。ILL 孤話会 (関東地区内のテレックス設置館が暫定的に構成メンバ 一となっている）は現在も活動を続けているが，関東地 区全館を対象に相互貸借業務の分科会或は研究会のよう
なものがあってもいいのではないかといら声が第 1 回の 秘談会の時から引き続いてあり, 今回の開催となった次 第である。

今回は 2 題の 研究発表と ILL 懇話会の 活動報告とし て相貸統計に関する問題が討議に付された。以下はその 抄録と質疑忘答の記録である。（文責 西岡）

\section{研究発㐮 I：相互貸借からみた雑誌利用統計 一わが図書館の特色 横浜市立大学図書館医学部分館 角田 昭夫}

（抄録）相互貸借・貸方の利用統計を出してみて，当館 の相貸上の利用構造の実態を探り, 又他館から何を期待 されているのかを考えてみた。方法は 1974 ・ 75 年の洋 雑誌について誌名別, 年代別に利用頻度を数えた。（利 用された雑誌数は 352 誌，2，356 件)，これを集計して 利用回数別誌数 - 件数分布表 (A表) と上位 27 誌のリ スト（B 表）を得た。A 表に利用回数毎に誌数, 累積誌 数, 百分率, 件数, 累積件数, 百分率を示した。B 表に は 1 位 Brain 他 26 誌について件数, 利用年代, 当館所 蔵巻年を示した。

$\mathrm{A}$ 表 : 2 年間で 1 度しか利用されなかった雑誌は 109 誌で,これは全利用誌数（352）の $30.9 \%$ と多いのに対 し全件数（2,356）からみるとわずか $4.6 \%$ にしかなら ない。 5 回までの累積誌数 249 誌 $(70.7 \%$ )に対し累積 件数は $23.8 \%$ と 4 分の 1 亿足りない。これは 申込まれ た件数が非常に沢山の雑誌に分散されていることを示し ている。一方 $21 \sim 146$ 回の雑誌は 27 誌（7.7\%）と少な いのに対して件数は 1,005 件と $42.7 \%$ を占めている。 これは特定の雑誌に利用が集中していることを示してい る。即ち利用回数別分布表においては底回数では分散度 が高く, 高回数では集中度が高くなる特性を示す訳であ るが当館ではこれが著しいと思われる。

$\mathrm{B}$ 表：ベスト 27 誌をみると所謂コアージャーナルと ユニークジャーナルの類別が確認される。コアージャー 
ナルは創刊年が古く諭文数の多い雑誌で当館所蔵もかな り揃っているものである。年代からみると 1930～60 年 代のバックナンバーの利用が多く最近のものは少ない。 これは新しいものは何処でも所蔵しているので, 古いも のを当館に期待したのだろう。一方ユニークジャーナル の方は交換誌が多く他館の所蔵の少ないものである。年 代からみると最近のもの程利用が多い。これは新しい諭 文程利用価值が高いという原則がそのまま生きているの だろう。B表についてまとめると当館は特定のコアージ ヤーナルのバックナンバーとユニークジャーナルの利用 を期待されている, と言えると思う。又この調査の中で 気付いた事だが, 当館所蔵雑誌で学内者用の雑誌と相互 貸借用の雑誌がかなり明確に分けられるように思う。同 じ雑誌の利用頻度統計でも学内利用のそれとはまったく 異なり相貸上の特徴が如実に現われてくる。非常に沢山 の要素があり, その要素分折が難しく現象認識から本質 認識までいくには,なかなか奥が深いように思われる。

裏田(慈恵)：Brain について, 1941 50年代の利用 が多いがこれは 1974〜75 年とも同じ傾向か, 欠号がな いので利用も高いと思われるが他館ではどういう所蔵状 況か調べてみたか。

角田：他館の状況は調べていない。調べるとおもし ろいと思う。Brainについては 1974〜 75 年についても 同じ傾向，1941〜50 年は戦争前後で，全国的な規模で 考えても所蔵している館はないと思う。横浜市大でもバ ックナンバーで揄えた。

\section{研究発表II：相互貸借における借りの分析} 一借りの件数と受入れ雑誌 数との相関性について 東邦大学医学部図書館

菅原 秀浩 田中 由美子

（抄録）相貸の借りは利用者の文献需要に対して自館が 保有していない時に発生する。状況としての次の式が成 り立つ。

相貸の借り $=$ 文献需要一自館保有 (文献需要)を一定とすれば(相貸の借り)は（自館保有） が多（少）であれば少（多）である。現実にこの仮定が 正しいと言えるか否か，又 (文献需要) はこの 2 項目に どんな影響をおよぼすか，この目的をもって調查を始め た。(相貸の借) は借りの件数を（文献需要）は利用者 の数に正比例するといら観点から学生数を除いた利用対 象数を（自館保有）は受入雑誌数をそれぞれ選んだ。
1970〜75 年における JMLA 加盟館統計からこの 3 項目 の揃っている 58 館の平均の推移と, 東邦大学のそれを 比較した。利用対象数と受入雑誌数では各年における 増減はあるものの東邦大学の推移は平均に近いものであ った。借りの件数は 1970 73 年では平均より多少多い 程度であったのが 1974 75 年には平均の $2 \sim 3$ 倍の急 上昇を示していた。特に 1975 年の件数は 4, 279 件で JMLA 加盟館中最高であった。この原因を探るために, 1975年東邦大学の相貸の借りの記録から私達の扱った東 邦大学非保有の雑誌文献 2,954 件について年代別, 非保 有別内容調查を行なった。年代別にみると 1960 年以降 の 16 年間が $72 \%$, 特に 1970 年以降の 6 年間 が $38 \%$ を 占めている。非保有内容では受入中の雑誌ではあるが久 落, バックナンバーなし, 受入中絶等々による非保有が $70 \%$ を占めている。以上のことから東邦大学では最近 図書館に向いてきた潜在的利用者の需要に対応しきれな い, 過去の文献蓄積の欠如が大きいと言える。次に JM LA 加盟館全体では借りの件数と受入雑誌数はどんな相 関をなしているのか, 又東邦大学はどんな位置にあるの かを調べた。3 項目の 1970～75 年における 58館全体の 総平均值, 標準偏差值を求め, これを用いて分類した。 借りの件数と受入雑誌数との 2 項目相関をみると最初の 仮定に沿った線上に各館が存在している。しかし次の 2 点に顕著なブレがあった。

1. 借りの件数(非常に) 少 $=$ 受入雑誌数 少…11館

2. " 非常に多= " 多…3 館 そこで利用対象数の分類を含めた 3 項目相関表を考察し た。するとブレの第 1 点は利用対象数の非常に少い館で あり，第 2 点はいずれも平均より多い館であった。以上 により借りの件数と受入雑誌数とは負の相関々係を持つ という最初の仮定は総体的に正しいと言える。但しこの 相関に対して利用対象数 (文献需要) による影響と借り の件数の急上昇館（東邦等）にみられるように館独自の 所蔵事情による影響とがブレを生じさせている。一

裏田 : 東邦のように相貸・借りの件数が急上昇を示す 要因として他にも考えられると思うが...

菅原 : 東邦の場合, 久落, バックナンバーなしという 面でのつめが足りないので結論は出せない。

裹田：研究者の数が増えている,というようなことで はない，東邦では最近雑誌を非常によく集めていると思 うが...

菅原 : 1970 年以降受入れの雑誌については借りが全 体の $6 \%$ \%しかなっていない,つまり自館の所蔵数が増 
えている。

裹田：それと急上昇をどら結びつけるのか。

菅原 : 急上昇の要因については事後調査ということで 逃げている。今後やりたい。

裏田：大きな理由として担当職員のサービスの質の向 上があるのではないか。

营原：潜在的利用者の眼を図書館に向けさせたという 点でそれは言えるかも知れない。しかしそれも自館独自 ではなく JMLA 依存という点に問題がある。

西岡 (東女) : 雑誌受入数, 所蔵数が増えると借りの件 数も増えるといらケース, その理由は…

菅原 : 所蔵内容の不充分さをカバーして不充実から充 実に向かっていることが要因として考えられる。

西岡 : 受入雑誌数の増加即ち図書館で得られる情報が 増えれば需要も高まり借りの件数も多くなることが推定 される。

营原 : 利用者数, 図書館の規模により受入雑誌数, 相 貸・借りの件数の相関々係もブレてゆく。又欠落, バッ クナンバーなし等所蔵内容による事情も無視できない。

角田（横浜市大）：菅原さんの発表を聞いていての感想 だが，雑誌数が少なくて借りの件数が多いと非常に負担 を感じる。横浜市は地方公共団体なので金づまりで予算 がなかなかおりない。それで交換雑誌でカバーしていか なければならない。

\section{研究発表III：相互貸借統計について}

\section{(ILL懇話会)}

東京女子医科大学図書館

三浦 健 (発表者)

東京慈恵会医科大学図書館

内山きぬ子森永 和代

慶応義塾大学医学情報センター

渡辺洋子 平沢 初枝

（抄録）相互貸借統計について，(1)現在の JMLA 統計 に対する意見, (2)担当者レベルで必要な統計で, 他のセ クションも利用できるもの, (3)将来の相貸業務を円滑に 運営するために必要な統計或はリストについて検討する。

1) JMLA 相貸統計の問題点として複写記入欄におけ る数值の記載範囲にはっきりした定義がないので, その 基準を明確にする必要がある。貸りの記入欄は JMLA 加盟, 非加盟館を何らかの形で区別して記入する。その 件数には謝絶件数も含めることにし，できれば別に謝絶 項目を設ける。借りの複写記入欄は実際に申込書を作成
した件数を記入する。又現在の統計に新設したい項目と して貸しの欄に海外利用の項目, 不要な項目として学内 複写の項があげられる。

2)検討の結果, 担当者レベルで必要と思われる統計と して, 月別統計, 館別統計, 誌名別統計, 謝絶内容統計 があげられる。月別統計は相貸業務における基本的な統 計であり, 年次統計の基礎となるものである。館別統計 は貸借における借りの方で申込み館のバランスを計るた めの資料となる。誌名別統計は雑誌収集の一つの目安と なるものである。謝絶内容統計は具体的な謝絶理由を統 計項目としてあげたものである。

3)ここでは海外申込みの誌名リスト, 関東ブロック外 に申込んだ雑誌のリストが検討された。前者では海外依 存の実情を把握するため, 後者ではブロック内充足度を 調查しようというものである。

司会(西岡)：今の発表にもありました相貸の問題点で もあります謝絶のことについてILL 懇話会 (久保田一独 協）から皆さんに提案があります。

久保田 (独協)：相貸業務のマイナス面である謝絶につ いて何らかの対策を立てなければならない。そこでまず その実態を調查するために内容（参照不完, 欠本等）ま で堀下げた統計をとってみたい。対象は関東地区各館。

西岡：ILL 想話会メンバーでやった謝絶内容統計をみ ると現状ではやむを得ないものもあるが，それでも約 15 \%が謝絶で戻ってくるのは問題だ。

篠原（山之内）：謝絶の項目についてまちまちであった といらのはどういらことか。

久保田：“その他”の項目に“未着”を含めているところ もあるし, “所蔵なし”, “欠本”等についても解釈がまち まちである。

西岡：JMLA 統計に謝絶の項目が新設されることにな ったが，これは一文献に対して何度謝絶されてもそれは 1 件, 又最終的に手に入れば 0 件となる。これでは謝絶 の実態は把握できない。

襄田 : 統計は継続的にか, 一定期間だけか。

久保田：継続的に出来たら面白いと思らが, 方法の詳 細についてはILL 㼊話会内部で更に検討する。又例え ば私の館の場合目録ミスによる謝絶が多いが, 現行医学 雑誌所在目録に原稿を出す時など気を付けるようにと注 文を出せる。

中村 (日大松戸歯)：謝絶項目の中に“調査中”というの があるが，それはどういう場合を想定しているのか

襄田 :「相互貸借マニュアル」作成の時にも検討した 
のだが，国立大学で会計調查の関係で"欠本”，“久号”と 言えないのでやむを得ず調查中”としている。私大には ほとんど関係がないと思う。

田中 (東邦)：東邦の場合, “行方不明”と“調查中”には きちんと定義がある。例ばえ一週間くらい前に書架にあ ったものがないといら場合は“調查中”，1年間ないのが “行方不明”, 2 年間なければ“欠本”。

裹田：JMLA「相貸マニュアル」ができたが，それに 謝絶項目の定義が載っている。それに沿って統計を出し てもらえれば大体の線は出るのではないか。

矢田 (順天堂)：「相貸マニュアル」の中でも"所蔵な し”と“欠本”についての区別がつかない。どう解釈した らいいのか

裏田：その点についてはマニュアル作成の時にももめ た。“所蔵なし”はあるタイトルが全然自館にない場合, “欠本”は巻単位で所蔵がない場合, “欠号”と“未着”の違 いについては, 例えば JAMA Vol. 236 No. 5 まで来てい て, No.4は届いていない, これは“欠号”か“未着”か, はっきりした結論は出ていない。まだまだ不明の部分も
多い,この「相互貸借マニュアル」は第一版なので今後 改訂していってほしい。

西岡 : ILL 㟴話会内部でやった謝絶統計をみると, 例 えば慶応は“製本中”が多い，慈恵でば次”が目立つ。 こういら数字を出さなければならないので困るところが あるかも知れない, 又担当者の作業量も大変なものだろ う。だが一度は実施する価値があると思う。

菅原：“その他”の項目にかなりまとまった数字が出て いるが,これはどらいうことか。

下村 (東医)：それは東医の場合であるが，この時期書 庫の改造で本が出せなかったことによる。

〔協会の統計委員である東邦の井上氏より委員 会内部の討議について説明があった。]

司会 : それでは久保田君の提案に対して反対意見もな いようですので, 受け入れられたといらことに致します。 ILL 㸸話会の方から調查依頼のありました時には御協力 をお願い致します。

以上 